\title{
A BREAK WITH THE PAST OR RESURGENCE OF AMATEURISM? PLACING OUR PANDEMIC ERA IN THE HISTORY OF COLLEGE TEACHING
}

Jessamyn Neuhaus

SUNY Plattsburgh

Since March 2020, everyone in higher education has heard the word "unprecedented" far too often. Yet this is an accurate adjective for college teaching during the Covid-19 pandemic. A nationwide emergency pivot to remote instruction never happened before. To be sure, some faculty navigating the new normal already possessed online teaching expertise. However, the proliferation of teleconferenced, webcam-enabled classrooms posed entirely new pedagogical problems. ${ }^{1}$ The question, "How do we implement technology in the college classroom?" didn't originate in 2020. ${ }^{2}$ But the question, "How do we implement technology in the college classroom during a global pandemic, in an era of political turmoil, economic devastation, social distancing, 'alternative facts', and no childcare or in-person schooling while also getting camera-ready for professional Zooming from our couch?" was utterly-wait for it-unprecedented.

Anyone trying to ascertain what the pandemic era may mean to college teaching can look to Jonathan Zimmerman's The Amateur Hour: A History of College Teaching in America. His analysis suggests both the potential for a break with the past as well as ways the powerful pull of history may lead to lost opportunities for improving teaching, post-pandemic. Zimmerman argues that in contrast to intellectual work and research, academia doggedly refuses to professionalize the labor of college teaching, instead relying on a cult of personality and occasional ad hoc reform efforts. But, as Robert Hampel notes in his review, "most of those initiatives fell short, and most professors continued to be classroom amateurs and research professionals."

Every educational developer and instructional designer encounters this deep-seated resistance to professionalizing college teaching. Programming aimed at helping faculty increase their teaching efficacy, even at institutions with robust, well-funded teaching centers, meets persistent resistance among academics to the idea of spending one's time and mental resources on pedagogical learning. Notwithstanding flourishing scholarship of teaching and learning (SoTL) and increased pedagogical training for graduate students, college teaching is still largely a solitary, closed-door profession, with few systemic opportunities for openly sharing teaching ideas and problems. Zimmerman points out that not much has changed since 1965, when one college president remarked: "As a group, college teachers have been loftily contemptuous of courses in education and absurdly vain about their innocence of any formal instruction in curriculum design, testing techniques, and formal classroom procedures" (9).

However, in the wake of the 2020 emergency pivot, faculty disdain for educational development and their "absurd vanity" about teaching amateurism wavered. As I said in a June 2020 interview with Inside Higher Ed about serving as the interim director of my college's teaching center that semester: "For the first time, college instructors became novice learners in so many ways. For the first time, it was acceptable, even desirable, for smarty-pants experts to say, 'I need some assistance; I'm not sure how to teach this right now.' It became culturally acceptable for people to just admit, 'I'm not totally sure how to do this.' That is so huge."3 Zimmerman's historical analysis puts into perspective exactly how huge it was, helping us further recognize the significance of that moment.

Discouragingly, he also demonstrates the endurance of amateurism in college teaching. Knowing exactly how long-lasting "the amateur hour" has been, it's hard to foresee a permanent revolution in academics' approach to

\footnotetext{
${ }^{1}$ For resources on Zoom-based teaching, see https://geekypedagogy.com/zoom.

${ }^{2}$ See for example Derek Bruff, Intentional Tech: Principles to Guide the Use of Technology in the College Classroom (Morgantown: West Virginia University Press, 2019).

${ }^{3}$ Doug Lederman, "Crisis and Opportunity for Faculty Development," Inside Higher Ed, June 3, 2020, https://www.insidehighered. com/digital-learning/article/2020/06/03/how-new-one-person-teaching-center-navigating-moment-peril-and.
} 
teaching being brought about by the crisis conditions of the pandemic era. In fact, those same working and living crisis conditions are creating the threat of serious burnout among college educators, which is directly linked to disinterest in teaching and indifference to student learning. ${ }^{4}$ And it's important to note that burnout and other burdens of pandemic era teaching are not evenly distributed among college educators. Systemic racism, ableism, sexism, and homophobia ensures that the challenges of college teaching, including mitigating student biases, fall more heavily on some instructors than others. Zimmerman writes that "the lack of tangible career-related returns on teaching remains the central barrier to improving it" (233). I would add that women, BIPOC, nonbinary, disabled instructors, women of color, and contingent faculty all face numerous additional obstacles to "career-related returns on teaching."

Furthermore, the deeply ingrained amateurism of college teaching before the pandemic will lead to lost opportunities in recording and documenting new pedagogical insights. Zimmerman notes that "the amateur status of teaching has meant that it is rarely documented-or recorded, or authenticated-in the ways that a truly professional practice would be" (11). While I agree with those who have cautioned against treating traumatized students like lab rats in a pandemic learning maze, rigorous study, wisdom of practice, and deliberate, systemic reflection are all vital parts of the Scholarship of Teaching and Learning. SoTL is one of our best weapons in the fight to improve pedagogical learning among college instructors but the threat of lost wisdom looms large today.

In this way, historians may be particularly well-suited to ensure that the pandemic era marks a break with college teaching's problematic past. Zimmerman's book is an example of how we wield the tools of our discipline to increase our understanding of why things are the way they are today, including how we teach. The global pandemic context and the Zoom-based classroom are new but the amateurish, individualistic approach to college teaching is anything but. Cultivating a pedagogical community of practice, knowing that you are not alone, is the cornerstone of the best educational development and SoTL. Because you are reading Teaching History, you already know the value of published work that helps us build our pedagogical content knowledge. Teaching History and other conferences offer additional, invaluable opportunities to increase productive discourse around college history teaching. As Zimmerman's works suggests, unless we actively seize these opportunities and disrupt "the amateur hour," the "dead hand of tradition" (164) will continue to write our curriculum and proscribe our pedagogy today and post-pandemic.

\footnotetext{
${ }^{4}$ Rebecca Pope-Roark, "Professor Burnout: How do You Identify and Destigmatize Faculty Burnout?” POD Network Annual
} Conference (2020). 